\section{Intersections}

Canadian Journal of Music

Revue canadienne de musique
Intersections CANADIAN JOURAL OF MUSIC

\title{
Iphigénie à Paris: Positioning Gluck Historically in Early Twentieth-Century France
}

\section{William Gibbons}

Volume 27, numéro 1, 2006

URI : https://id.erudit.org/iderudit/1013158ar

DOI : https://doi.org/10.7202/1013158ar

Aller au sommaire du numéro

\section{Éditeur(s)}

Canadian University Music Society / Société de musique des universités canadiennes

\section{ISSN}

1911-0146 (imprimé)

1918-512X (numérique)

Découvrir la revue

Citer cet article

Gibbons, W. (2006). Iphigénie à Paris: Positioning Gluck Historically in Early Twentieth-Century France. Intersections, 27(1), 3-15.

https://doi.org/10.7202/1013158ar

\section{Résumé de l'article}

Dernier des principaux opéras de Gluck à être représenté après une période d’oubli, Iphigénie en Aulide a été produit à l'Opéra-Comique de Paris en décembre 1907. La réception critique qui suivit opposa Vincent d'Indy, féroce critique de cette production, et son directeur, Albert Carré. D’Indy répliqua dans les semaines suivantes en dirigeant l'ouverture d'Iphigénie à titre de rectificatif musical de la présentation de l'Opéra-Comique. Cet événement inhabituel met en évidence le problème historiographique posé par Gluck aux critiques français du début du XXe siècle : sa musique était-elle orientée vers le passé des tragédies lyriques de Lully et Rameau ou préfigurait-elle les drames musicaux wagnériens du XIXe siècle? La production d'Iphigénie à l'Opéra-Comique en 1907 et ses séquelles résume le combat visant à intégrer Gluck dans de nouvelles, et souvent concurrentes, trames de l'histoire de la musique.
All Rights Reserved (C Canadian University Music Society / Société de musique des universités canadiennes, 2007
Ce document est protégé par la loi sur le droit d'auteur. L’utilisation des services d'Érudit (y compris la reproduction) est assujettie à sa politique d'utilisation que vous pouvez consulter en ligne.

https://apropos.erudit.org/fr/usagers/politique-dutilisation/ 


\section{Iphigénie à Paris: Positioning Gluck Historically in Early Twentieth-Century France}

\section{William Gibbons}

On 18 December 1907, Gluck's opera Iphigénie en Aulide appeared on the Parisian stage, after an absence of more than three-quarters of a century. ${ }^{1}$ Produced at the Opéra-Comique under the direction of Albert Carré and featuring the famed Lucienne Bréval in the title role, this production again drew French attention to Gluck and his works, which were lauded in the press, and consequently by the public. By 1907, Gluck was already a major feature on the Parisian stage-Iphigénie en Aulide was actually the last of his five great "masterpiece" operas to be revived in fin-de-siecle Paris; ${ }^{2}$ however, this performance was anything but a token revival of another Gluck opera. I contend that this production and the following musical and critical reception represent a battleground in the fight over Gluck's place in French music history.

Positioning Gluck in this manner was no mere academic exercise. Through the late nineteenth and early twentieth centuries, France enacted a major earlymusic revival. ${ }^{3}$ New editions of early French music were increasingly common, and more and more concert space was given over to the performance of "ancient" works. Around the turn of the century Gluck came to assume a major place in this revival, but in a complex position. Though German by birth, Gluck lived and worked for an extended period of time in Paris and so was more or less adopted by twentieth-century critics seeking to expand France's musical heritage (an analogous situation to Handel's in England). On the one hand, his "French" works could be seen as the culmination of the tragédie lyrique tradition epitomized by the works of Lully and Rameau. On the other, Gluck as operatic reformer pointed ahead to Wagner and the integration of music and poetry associated with the music-dramas of Bayreuth.

To a certain extent, these two positions could be held simultaneously, particularly given Gluck's dual German/French national identity. Several influential

I would like to thank Annegret Fauser, Tamara Levitz, Catrina Flint de Médicis, and the anonymous reviewers of this journal for their exceedingly helpful comments on various drafts of this article.

1 The opera ran for 14 performances, with the following lead cast members: Lucienne Bréval (Iphigénie), Suzanne Brohly (Clytemnestra), Rose Heilbronner (Diane), MM. Ghasne (Agamennon), Léon Beyle (Achille), Félix Vieuille (Calchas), Louis Azéma (Patrocle), Guillamat (Arcas). (Wolff 1953, 95)

2 Gluck's five "masterpieces" are generally considered to be Orphée et Euridice, Iphigénie en Tauride, Alceste, Armide, and Iphigénie en Aulide, the first four of which were revived in Paris in 1896/1899, 1899, 1904 , and 1905 , respectively.

3 For the most complete analysis of this shift towards early music in France, see Katharine Ellis, Interpreting the Musical Past: Early Music in Nineteenth-Century France (2005). 
figures on the Parisian musical scene tried to glorify the composer by turning his work into a musical fulcrum-balancing the past on one side and the future on the other. This approach enabled the critics to interpret him both as the last great composer in the tradition of the tragédie lyrique and as a revolutionary. Such a balance was fairly easy to maintain in the abstract. The 1907 OpéraComique production of Iphigénie en Aulide, however, seems to have polarized critics, forcing them towards one side or the other.

One particular incident encapsulates this battle: shortly after the première of Iphigénie under Carrës direction, Vincent d'Indy wrote a vitriolic letter-d'Indy biographer Léon Vallas describes it as "sévère à l'extrême" (Vallas 1950, 71) - to the editor of the journal Comodia (later reprinted in Le Guide musical) harshly criticizing Carré and his interpretation of the work:

$[\mathrm{N}]$ othing is on point in this interpretation: neither the recitatives, too solemn; nor the arias, totally lacking life and expression; nor the orchestra, perfect from the point of view of the notes, absolutely off the mark from the point of view of the accent and style; nor even the ballet... (Le Guide musical, 5 January 1908$)^{4}$

Within weeks of the Opéra-Comique performance, d'Indy responded by conducting the overture to the opera at the Concerts Lamoureux (to which he had recently been appointed to the position of deputy to Chevillard)-openly criticizing the Opéra-Comique. This course of action was dangerous for an operatic composer, and set in motion d'Indy's estrangement from the institution (Thomson 1996, 162). This highly unusual response raises an important question: what about Carrés production of Iphigénie was so provoking to d'Indy and others?

The answer to that question lies partly in the history of the opera. The work premiered at the Académie Royale de Musique on 19 April 1774, one year after Gluck relocated to France. While Gluck was certainly familiar with the tragédies lyriques of Lully and Rameau, Iphigénie en Aulide was his first opera originally conceived with a French libretto in mind. It was composed, as many critics have pointed out, with no obvious venue for performance, and quite possibly would have not been produced in Paris at all had it not been for the support of Marie Antoinette, Gluck's former singing pupil. This fact led to the impression of Gluck entering onto the Parisian scene triumphantly, with the French monarchy supporting his efforts.

While the Classical source of the Iphigenia story is Euripides, the libretto for Gluck's opera was adapted by the French writer Marie François Louis Gand Leblanc Roullet from Jean Racine's seventeenth-century version of the famous work. Iphigénie en Aulide was successful, but was swiftly overshadowed by the successes of the French versions of Orfeo ed Euridice, Armide, and Alceste

4 “ $[R]$ ien n'est au point dans cette interprétation : ni les récits, trop solennels; ni les airs, manquant totalement de vie et d'expression; ni l'orchestre, parfait au point de vue de la note, absolument à côté au point de vue de laccent et du style; ni même le ballet..." D'Indy also referred to the performance in a letter as the "massacre d'Iphigénie au profit d'une affaire accessoire dans laquelle l'outrecuidance ne le cède quà la mauvaise foi." Letter to Octave Maus, 3 January 1908. (Indy 2001, 693) 
(Hayes 2006). Iphigénie en Aulide was revived periodically throughout the late eighteenth- and early nineteenth centuries, but it fell into relative obscurity in Paris as the century went on.

Unquestionably, Hector Berlioz was Gluck's greatest advocate during the nineteenth century. Throughout his career as writer and conductor, Berlioz spent considerable time and energy performing and promoting Gluck's operas in France, ${ }^{5}$ and it is certainly possible that the Berlioz centenary in 1903 helped encourage the general revival of Gluck's works in early twentieth-century France. ${ }^{6}$ However, his focus and admiration were largely aimed towards the Italian reform operas: Orfeo (Orphée), Alceste, and Armide. While Joël-Marie Fauquet points out that the number of musical examples from Gluck in Berlioz's Traité d'instrumentation et d'orchestration modernes (1843) is equal to the number of examples taken from Beethoven-an impressive figure-only two of the 17 Gluck examples come from Iphigénie en Aulide (Fauquet 2000, 204). ${ }^{7}$

Another nineteenth-century composer did single out Iphigénie en Aulide for attention: in 1847 Richard Wagner adapted the work for a performance in Dresden. ${ }^{8}$ The overture held particular significance for Wagner. As early as 1841, he showered the work with praise in an article entitled "De L'Ouverture" in La Revue et gazette musicale de Paris (10, 14, 17 January 1841), using it as his primary example for the dramatic capabilities of the operatic overture. Furthermore, in 1854 he published an article in the Neue Zeitschrift für Musik (1 July 1854) focusing on his adaptation of the overture to Iphigénie. ${ }^{9}$ Wagner's seal of approval on the work, as well as his acknowledgement of its importance in his own development, encouraged French Wagnerians to see the work in the light of the "modern" music-drama. Notably, this version was also performed in late 1907-the same year as at the Opéra-Comique-but in Vienna under the baton of Gustav Mahler (Hayes 2006). Closer to home, the Schola Cantorum, led by d'Indy, also produced at least large excerpts from Iphigénie

5 For more details on Berlioz's advocacy of Gluck's music, see Joël-Marie Fauquet, "Berlioz and Gluck," in The Cambridge Companion to Berlioz (Fauquet 2000, 199-210).

6 See in particular Berlioz's writings on Gluck in A Travers Chants (Paris: Gründ, 1971). The relevant sections were excerpted and translated in Gluck and His Operas, with an Account of Their Relation to Musical Art, trans. Edwin Evans (Westport, Conn.: Greenwood, 1973).

7 Fauquet actually states that only one example comes from Iphigénie en Aulide, but this is not the case. One example comes from the overture, and another from Agamemnon's aria "Peuvent-ils ordonner qu'un père."

8 Barry Millington has succinctly summarized Wagner's changes by saying that "[h]is arrangement was, according to the lights of his time, a sincere and sensitive attempt to present the opera in an acceptable form. Finding the arias and choruses 'disconnected', he linked them by means of preludes, postludes and transitions... The orchestration was also revised but with restraint and always with the aim of highlighting features of Gluck's own score. His major alteration was to eliminate what he regarded as the predictable and sentimental marriage of Achilles and Iphigenia at the end; in order to effect this return to the spirit of Euripides it was necessary to introduce a new character (Artemis) as well as some recitatives."(Millington 1984, 31). Wagner's own comments on adapting the work may be found in Richard Wagner, My Life (1992, 337-40).

9 For more on Wagner's view of the importance of the overture to Iphigénie, see Thomas S. Grey, "Wagner, the Overture, and the Aesthetics of Musical Form." (Grey 1988) 
on 1 February 1907 (Indy 1927, 231). ${ }^{10}$ This performance of the opera received very little attention in the press, particularly when compared with the soonto-follow Opéra-Comique production. It seems likely, however, that Wagner's adaptation was used, since d'Indy conducted the overture in Wagner's version at the Concerts Lamoureux.

The proximity of the Opéra-Comique and Schola productions of Iphigénie undoubtedly exacerbated d'Indy's distaste for Carrës interpretation, ${ }^{11}$ particularly given that, in contrast with the quiet reception of the Schola's productions, the Opéra-Comique Iphigénie in 1907 stirred up a great deal of activity in French periodicals. Most major artistic publications reviewed the production and some also reviewed d'Indy's musical rebuttal. Almost without exception, the critics lauded the quality of Carrés performers, and Lucienne Bréval in particular. George Pioch, for example, contended in Musica (February 1908) that "here is perhaps the greatest achievement of her career." 12 Even d'Indy praised the quality of the performers and sets: "The singers are artists of the first order, the orchestra is admirably unified, not a note out of place, the sets are superb, the ballet... oh! the ballet above all is a veritable charm for the eyes..." (Le Guide musical, 5 January 1908). ${ }^{13}$ Paul Milliet, editor of Le Monde artiste, joined d'Indy in praising the sets, but went much farther, praising Carrés production in near-rhapsodic language:

Albert Carré has the genius of decoration, of staging, of theatrical life, and he invested Iphigénie with all the artistic splendors that he knows how to make on its tiny stage... [He] occupies a special place in the theatrical world and he will leave a lasting impression on the difficult art of rendering that collection of visual feelings that Wagner called the world of the light, Lichtwelt... The director of the Opéra-Comique exceeded himself with Iphigénie en Aulide, and Gluck's music was revealed to us to be richer, deeper of feeling, of a broader and subtler suggestion. (Le Monde artiste, 22 December 1907) $)^{14}$

10 This concert is unfortunately listed without any details, so we cannot be sure exactly in what form the opera appeared.

11 Léon Vallas cites mainly personal reasons for d'Indy denunciation of Carrés performance: not only had Carré had rejected the opera d'Indy's friend Pierre de Bréville, but he had also backed out of the production of d'Indy's own work Phédre et Hippolyte. While I certainly do not deny that personal dislike for Carré may have exacerbated the vehemence with which d'Indy attacked the Opéra-Comique performance of Iphigénie, I give d'Indy somewhat more credence in his arguments, which I feel transcend the level of a petty squabble. Vallas, Vincent $d$ 'Indy, Vol. 2, 71-73.

12 “... voici peut-être le plus haut effort de sa carrière." In contrast, Henri de Curzon claimed in Le Guide musical that "Mlle Bréval, si ardente, si dramatique, d'un tempérament si passioné sest trompée en prenant celui d'Iphigénie." (Le Guide musical 22 December 1907)

13 "Les chanteurs sont des artistes de premier ordre, l'orchestre est admirable d'ensemble, pas une note ne manque à l'appel, les décors sont superbes, le ballet... oh! le ballet surtout est un véritable charme pour les yeux..."

14 “... M. Albert Carré a le génie de la décoration, de la mise en scène, de la vie thêâtrale, et il a paré Iphigénie de toutes les splendeurs artistiques qu'il sait créer sur sa scène minuscule... [Il] occupe une place à part dans le monde théâtral et il laissera un souvenir durable dans lart difficile de rendre un drame lyrique humain, par cet ensemble de sensations visuelles que Wagner appelait le monde de la lumière, Lichtwelt... Eh bien, le directeur de l'Opéra-Comique s’est surpassé lui-même dans Iphigénie 
It would appear that the production of Iphigénie (and possibly the ensuing debate) prompted a more general interest in positioning Gluck historically. One particularly vivid example may be found in Le Ménestrel, which in December 1907 began a serial publication of "Soixante ans de la vie de Gluck," written by musicologist and Wagnerian Julien Tiersot. This lengthy biographical study continued throughout the entirety of 1908 and into 1909; Gluck received more attention in Le Ménestrel than any other composer during those years.

One can see in the critical reception of Iphigénie en Aulide a microcosm of the struggle to place Gluck historically. Many critics emphasized the connection between Gluck and France's musical past, presenting Gluck as the last in the line of great French masters. Others, however, positioned him primarily as a predecessor to Wagner. Though the latter category may have been less densely populated, it was bolstered by d'Indy's stature in French music, as well as by his performance of Iphigénie's overture. Examining both perspectives on Gluck's position in music history yields useful information about conflicting perceptions of early music in Paris.

\section{IPHIGÉNIE AND THE Music OF THE PAST}

As one would expect, connecting Gluck to the French musical past through Iphigénie en Aulide depended on the creation of a direct line between him and the prevailing musical and cultural thought of eighteenth-century France. One of the key figures in this effort was Romain Rolland, who in his Musiciens d'Autrefois (1908) spent a great deal of time connecting Gluck to the traditions of the Encyclopedists. "Gluck's revolution," Rolland points out quite early in his discussion of the composer, "was not due to Gluck's genius alone, but to a whole century of thought as well. It had been prepared, foretold, and awaited by the Encyclopedists for twenty years" (Rolland 1908, 207). ${ }^{15}$ For Rolland Gluck serves a near-messianic role, fulfilling the operatic prophesies of the eighteenth century.

Iphigénie en Aulide was the perfect opera for encouraging such an interpretation. In particular, Gluck's choices of the topic and libretto were given special significance by early-twentieth-century critics. Rolland cites Diderot's Troisième Entretien sur le Fils Naturel (1757), which uses Racine's Iphigénie en Aulide as its example of a text that could be set fruitfully by a reformer of opera due to its expressivity and lyric qualities (Diderot 1967, 110-3). ${ }^{16}$ Furthermore, Rolland posits that Gluck was probably familiar with Francesco Algarotti's Saggio Sopra l'Opera in Musica (1755) (published in the May 1757 Mercure de France as Essai

en Aulide, et les musiques de Glück [sic] nous ont été révélées plus riches, plus profondes d'impression, d'une suggestion plus étendue et plus subtile."

15 "La révolution de Gluck... ne fut pas l'œuvre du seul génie de Gluck, mais de tout un siècle de pensée. Elle était préparée, annoncée, attendue depuis vingt ans par les Encyclopédistes." All translations of Rolland are taken from Blaiklock's Some Musicians of Former Days.

16 In response to one of Clytemnestra's passages, for example, Diderot claims that: "Je ne connais, ni dans Quinault, ni dans aucun poète, des vers plus lyriques, ni de situation plus propre à l'imitation musicale." He goes on to rhapsodize about the suitability of Racine's play for operatic setting for several pages. 
sur l'Opéra), which included a libretto based on Euripides and Racine's text as an example of future operatic reforms (Rolland 1908, 225). From an early twentieth-century standpoint, also, Racine was an appealing choice, connecting Gluck further to the golden age of French arts.

While Rolland's criticism tied Gluck to eighteenth-century French thought, one would expect that associating him with the Encyclopedist tradition would also distance the composer from Rameau and the tragédie lyrique. However, Rolland is able to associate Gluck with both Rameau and Rousseau by minimizing the significance of the infamous querelle des bouffons: "if the Encyclopedists came quickly to side with Rousseau and the Italian opera [against Rameau], it was because they were incensed by the uncivil stupidity of the partisans of French opera" (Rolland 1908, 213n). ${ }^{17}$ This conjecture neatly sidesteps the necessity of allying Gluck with either side of this conflict, and allows the composer to be depicted as both faithfully following in Rameau's footsteps and eagerly responding to Rousseau's call for operatic reform.

This association with Rameau was emphasized in much of the critical discourse surrounding the revival of Iphigénie in 1907. For example, Gabriel Fauré wrote in Le Figaro (19 December 1907) that "Lully and Rameau had marked the route; Gluck, with his ardent, passionate, and profoundly human genius, was to widen it." ${ }^{18}$ Similarly, in his review of Iphigénie (La Revue musicale, 1 January 1908) music historian Henri Quittard stated that by the 1774 première of Iphigénie "[t]he art of Lully, of Campra, of Rameau is already the art of Gluck... Iphigénie en Aulide is the first homage of the genius of Gluck to the genius of the French masters, in whom he recognized his true precursors and whom he overshadowed in realizing more completely what they had conceived." ${ }^{19}$ He further goes on to name the opera "the masterpiece of Baroque [ancien] French opera," a grand claim that certainly seems to position Iphigénie looking backwards as opposed to towards the future. ${ }^{20}$

This historical placement of Gluck was not a twentieth-century development. Félix Clément, for example, maintained in his Histoire de la Musique (1885) that

17 “Si, pourtant, les Encyclopédistes ne tardèrent pas à prendre violemment parti pour Rousseau et pour lopéra italien, c'est qu'ils furent exaspérés par la brutalité scandaleuse avec laquelle les partisans de lopéra français les combattirent."

18 "Lulli et Rameau avaient tracé la route; Gluck, avec son génie ardent, passionné, profondément humain, devait l'élargir."

19 "Lart de Lulli, de Campra, de Rameau, c’est déjà l’art de Gluck... Iphigénie en Aulide est le premier hommage du génie de Gluck au génie des maitres français, en qui il reconnaissait ses véritables précurseurs et qu'il allait faire oublier en réalisant plus complètement ce qu'ils avaient conçu."

20 "le chef-d'œuvre de l'ancien opéra français." This positioning of Gluck is not surprising given Quittard's primary focus on music of the seventeenth century. Connecting Gluck with the French musical past, then, would require connecting him with those traditions. As Catrina Flint de Médicis has pointed out, all "early music" was not created equal in fin-de-siecle Paris. There was a significant distinction between the treatments of seventeenth- and eighteenth-century music in French scholarship (and performance) of this time, with one often being privileged over the other depending on the historical and political value systems of the author (or performer). For more, see Catrina Flint de Médicis, "The Schola Cantorum, Early Music, and French Nationalism from 1894 to 1914 ” (Ph.D. diss., McGill University, 2006), especially 26-7. 
Iphigénie en Aulide... was the bright demonstration of a new musical genius rather than the blossoming of a new art... The ideas published by the celebrated Bohemian composer in his letters and developed by his partisans were essentially French and had been put into practice by Lully, by Campra, and by Rameau, above all in Castor et Pollux. (Clément 1885, 529) ${ }^{21}$

This extract, though predating the 1907 production, succinctly places Gluck in line with Rameau and Lully, making his musical "revolution" more a matter of developing preexisting ideas rather than an entirely new direction of musical thought. This approach serves to minimize Italian and Austro-German contributions to eighteenth-century opera, helping to reinforce the image of Gluck as French as opposed to German. It also enhances France's role in the development of opera after Gluck, since any composer influenced by him would have been emulating an "essentially French" style. However, examining history in this way also paints Gluck as a composer primarily oriented towards the past. This way of positioning him was at odds with a more forward-directed view of music history, such as the one held by d'Indy and those of like mind.

\section{IPHIGÉNIE AND THE MUSIC OF THE FUTURE}

In the debate around the turn of the century, no one denied Gluck's relationship to his French predecessors. The key point of contention seems rather to have been Gluck's relationship to the composers that followed him, and, specifically, to Wagner. As Ellis has demonstrated, for d'Indy and his group the worth of "early" composers lay in "the proximity of their musical styles to that of the master of Bayreuth" (Ellis 2006, 112). ${ }^{22}$ In order for d'Indy's teleological view of music history to work, Gluck had to point forward all the way to Wagner and beyond.

D'Indy, of course, was not the only critic to place Gluck-and Iphigénie-in line with Wagner, only the most prominent. Julien Tiersot, in his 1910 biography of Gluck, seizes upon the composer's preface to Alceste, in which Gluck rejected the excesses of Italian opera seria and set forth his principles of reform, as a "déclaration des droits" for operatic composers (Tiersot 1919, 231). ${ }^{23}$ In response to the perennial issue of the relationship between the music and the poetry-perhaps Gluck's most prominent reform-Tiersot quotes Wagner directly and then embarks on an excursus defending him from detractors. ${ }^{24}$ It is worth noting, however, that Tiersot also points out that Gluck "never had the

21 "L'Iphigénie en Aulide... fut plutôt léclatante manifestation d'un nouveau génie musical que léclosion d'un art nouveau... Les idées publiées par le célèbre compositeur bohème dans ses lettres et développées par ses partisans étaient essentiellement françaises et avaient été mises en pratique par Lulli, par Campra et même par Rameau, surtout dans Castor et Pollux."

22 Ellis is here specifically referring to the value given to composers in d'Indy's Cours de composition musicale.

23 Tiersot was certainly not the first in France to place such an emphasis on the preface to Alceste; François-Joseph Fétis, for example, felt the document to be of sufficient importance to publish it in its entirety in Gluck's entry in his Biographie Universelle des Musiciens ( $2^{\text {nd }}$ Ed., Paris: Firmin-Didot, 1883-4, reprinted Bruxelles: Culture et civilisation, 1972).

24 Tiersot, Gluck, 235-7. 
thought of breaking the molds used by Lully and Rameau, but on the contrary... his highest ambition was to continue their traditions" (Tiersot 1919, 234) ${ }^{25}$ This caveat aside, Tiersot focuses strongly on Gluck's relationship to the future, demonstrating how the composer essentially foreshadowed the nineteenth-century music drama.

Another significant figure who saw in Gluck the first steps on the path to Bayreuth was Claude Debussy. While the Wagnerite Tiersot saw this as a clearly positive move, however, Debussy saw Gluck as "a disaster for French music" (Nichols 1998, 109) for the same reasons. Léon Vallas astutely pointed out in the 1920s that "Debussy systematically opposed to Rameau, the true Frenchman, the German musician, Gluck, who usurped his colleague's place. According to him, Gluck was the hereditary enemy who broke through our [French] national tradition and destroyed our music" (Vallas 1929, 69). Debussy further explicated Gluck's crimes in a sarcastic open letter addressed to Gluck directly (Gil Blas, 23 February 1903):

From having known you [Gluck], French music gained the unwanted benefit of falling into the arms of Wagner; I like to imagine that, without you, not only would that not have happened, but then French music wouldn't have asked its way so often from people only too ready to lead her astray. ${ }^{26}$

However sharply Tiersot and Debussy may have diverged in their opinions of Wagnerian influence on French music, their opinions regarding Gluck's historical placement are not so dissimilar. Both figures saw the composer of Iphigénie as guiding French music down a path that would culminate in Tristan, whether for good or ill.

Jean d'Udine, however, in his own biography of Gluck, saw the relationship between the two composers in a different light. While Tiersot and Debussy found in Gluck a forerunner to Wagner, d'Udine saw the later composer as derivative. Gluck, he says, "imagined, well before Wagner, the 'unending melody,' with the advantage over the author of Tristan and the Ring that he did not fear to depart from either in the sense of the recitative or in that of the aria" (Udine 1906, 63). ${ }^{27}$ Even more damning, d'Udine states explicitly that

the colossus of Bayreuth, who believed himself to be a good Gluckist, was not... The Wagnerian 'unending melody' is a sophism; sophism defended genially by an incomparable orchestra, but sophism all the same...[T]he disciples of Wagner, Humperdinck, Vincent d'Indy, and Alfred Bruneau, for example, are outside of the Gluckist tradition each time that they re-

25 Gluck "n’a jamais eu la pensée de briser les formes utilisées par Lulli et Rameau, mais, au contraire... sa plus haute ambition fut de continuer leurs traditions."

26 "De vous avoir connu, la musique française a tiré le bénéfice assez inattendu de tomber dans les bras de Wagner; je me plais à imaginer que, sans vous, ça ne serait non seulement pas arrivé, mais lart musical français n'aurait pas demandé aussi souvent son chemin à des gens trop intéressés à le lui faire perdre." (Debussy 1987, 102)

27 "il imagina, bien avant Wagner, la mélodie continue, avec cet avantage sur l'auteur de Tristan et de la Tétralogie, qu'il ne craignait de s'en écarter ni dans le sens du récitatif, ni dans celui de l'air." 
main slaves to the aesthetic of the leitmotiv and that they systematically avoid the straightforward forms, the true lyric forms. (Udine 1906, 121) ${ }^{28}$

In his letter to Comæedia condemning the production of Iphigénie en Aulide at the Opéra-Comique, cited previously, Vincent d'Indy never mentions Wagner's name. Behind his words and actions, though, a Wagnerian ideology is in play. When answering the self-imposed question of what was missing from Carrés production of the opera, d'Indy answers: "Oh! My God. It is a very simple element, quite banal-but essential: what is missing is life. In music, life is called expression, and without expression, no music" (Le Guide musical, 5 January 1908).$^{29}$ It would seem that the tempi of the Opéra-Comique performance were too rigid for d'Indy, but that alone hardly seems cause for such concern. A new depth to the complaint emerges, however, when one considers that the "rigidity" of the tempo may be a performance-practice issue. Continuing his tirade in favor of expressivity in the performance of Gluck's music, d'Indy somewhat defensively iterates what amounts to an artistic credo: "Do not come talk to me about style, about tradition: a style that is not expressive is false, a tradition that is bad merits nothing other than to be abolished." 30 The problem with Carrés performance in Paris was not merely an issue of distasteful tempi, but rather of the music sounding moribund to d'Indy's ears. How could this problem be solved? "[I]n all the works of Gluck," d'Indy informs us,

there is, so to speak, not a recitative, not an aria that must be said and sung in tempo; the music being held to follow and to clasp closely the meaning of the words, it follows that the tempo must be sped up or slowed down always following the exigencies of the drama... [T] here are not, there cannot be, in the dramatic arias of Gluck, three measures that keep the same tempo; sometimes one encounters two or three tempi in a single measure. ${ }^{31}$

Again, in the description of the ideal performance of Gluck, d'Indy describes a work that begins to sound more like the performance of a Wagnerian musicdrama (or d'Indy's own works) than a revival of the work of an eighteenthcentury master.

Additionally, when he performed the overture to Iphigénie at the Concerts Lamoureux, d'Indy chose to present Wagner's 1847 version of the work (which

28 "le colosse de Bayreuth, qui se croyait un bon gluckiste, ne létait point... La 'mélodie continue' wagnérienne est un sophisme; sophisme défendu génialement par un orchestre incomparable, mais sophisme tout de même... [L]es disciples de Wagner, MM. Humperdinck, Vincent d'Indy et Alfred Bruneau, par exemple, sont hors de la tradition gluckiste, chaque fois qu'ils demeurent esclaves de l'esthétique du leitmotiv et qu'ils fuient systématiquement les formes carrées, les vraies formes lyriques."

29 "Oh! mon Dieu, c'est un élément bien simple, bien banal - essentiel cependant : ce qui manque, c'est la vie. En musique, la vie se nomme expression, et sans expression, point de musique."

30 "Qu'on ne vienne point me parler de style, de tradition : un style qui nest pas expressif est faux, une tradition que est mauvaise ne mérite pas autre chose que dêtre abolie."

31 "[D]ans tout l’œuvre de Gluck, il n’y a, pour ainsi dire, pas un récitatif, pas un air qui doive être dit et chanté en mesure; la musique étant tenue de suivre et de serrer étroitement le sens des paroles, il s'ensuit que le mouvement doit être accéléré ou ralenti tout le temps suivant les exigences du drame... [I] I n'y a pas, il ne peut pas y avoir, dans les airs dramatique de Gluck, trois mesures que gardent le même mouvement; parfois même, on rencontre deux ou trois mouvements différents dans une seule mesure." 
included a closing section by the later composer, designed to facilitate concert performance). Such a choice is significant; performing the overture in that version was surely a way of connecting Gluck more closely with Wagner. A performance of Iphigénie en Aulide that did not do so would be unacceptable; after all, as we have already seen Wagner had singled out this work on several occasions. For d'Indy, musical progress worked only in one direction; a performance that pointed Gluck towards the music of Rameau and Lully would be retrogressive at best and unbearable at worst, as d'Indy's reaction demonstrates.

D'Indy's performance of the overture to Iphigénie was not an unqualified success; clearly, some critics preferred a more "authentic" performance of the music. Jean Marnold, writing on d'Indy's performance in the Mercure de France (16 February 1908), found that

hearing this admirable music panting in convulsive starts interspersed with sudden developments, one has the impression of a very old lady, breathless, flushed, painful to watch, wanting to try to waltz, with her legs made numb by age and her height stiffened by the bows of the minuet. ${ }^{32}$

Similarly, Henri Quittard wrote that the "public seemed disoriented" ("le public a semblé...dérouté") by the performance. Furthermore, he went on to make a strong case against d'Indy's tactics:

I wish strongly, for my part, that everywhere, even at the Schola, the idea would sink in that early music is still music-that it is necessary to strive to bring out freely the feeling and meaning, that it is necessary to explore them patiently, without ceasing, and that there is no reason to freeze the feelings of the old masters under the icy crust of a majestically impassive solemnity. I also find that Wagner took a very great liberty with Gluck in adding to the original overture, which does not conclude, a developed and truly personal peroration. (La Revue musicale, 1 February 1908) $)^{33}$

Quittard, while acknowledging that performers must find emotion and meaning in early music, suggests that meaning may be found in the music itself, and not through adaptations like Wagner's or by Romanticized performances of the music. Clearly, he and others who shared his opinions felt that d'Indy's approach brought Gluck too close to the realm of Wagnerian aesthetics.

The 1907 Parisian production of Iphigénie en Aulide - and its receptionprovides us with a clear example of some musical tensions of early twentiethcentury France. While all participants were interested in celebrating the glories

32 “... à entendre haleter cette admirable musique en des soubresauts convulsifs coupés de soudains fignolages, on avait l'impression d'une très vielle dame essoufflée, cramoisie, pénible à regarder, pour vouloir essayer de faire un tour de valse avec ses jambes engourdies par làge [sic] et sa taille guindée aux révérences du menuet."

33 "Je souhaiterais fort, pour ma part, que partout, même à la Schola, on se pénétrât de cette idée que la musique ancienne reste de la musique, qu'il faut s'attacher à en faire librement ressortir le sentiment et la signification, qu'il faut les chercher patiemment, sans cesse, et qu'il n'y a aucune raison pour figer la sensibilité des vieux maitres sous la croûte glacée d'une solennité majestueusement impassible. Je trouve aussi que Wagner a pris avec Gluck une bien grande liberté en ajoutant à louverture originale, qui a conclut point, une péroraison développée et véritablement personnelle." 
of France's musical past, they differed significantly in terms of how this celebration should take place. The 1907 performance of Iphigénie en Aulide at the Opéra-Comique seems to have had the effect of placing the work into the historical canon as a musical artifact. This attitude was not uncommon in fin-desiècle Paris. At the 1889 Paris Exposition Universelle, for example, musical instruments-particularly harpsichords-from the past were shown prominently in a museum-like context (Fauser 2005, 27-42). Similarly, an increasing number of performers-notably Wanda Landowska and Louis Diémer-presented significant amounts of early music to audiences, with an increasing focus on performance practice. ${ }^{34}$ By contrast, rather than celebrating the music of the past as historical artifacts, d'Indy's performance of Iphigénie's overture at the Concerts Lamoureux brought the music into the present via Wagner's adaptation.

Gluck was a key figure in this positioning of France's musical history, and Iphigénie en Aulide was an important work for this task, as we have seen. All of the French musicians and critics explored here were in agreement about the significance of the work and its potential for reinforcing Gluck's image as a "French" composer. What this study demonstrates, however, is the divergence of opinions about how to work Gluck into historical narratives; while some saw Gluck primarily as a way of celebrating the past, others saw him as a pathway to the future. By pointing Gluck's music towards the tragédie lyrique tradition of Rameau and Lully, critics were able to lay claim to Gluck as a truly French composer, minimizing the "outsider" influence on French music-a highly desirable result for French music historians. However, positioning Gluck as a composer of essentially French-baroque style music minimizes the scope of his compositional innovations. Since, as we have seen, d'Indy's vision of music history depended on Gluck to herald the music of the future, this less forward-leaning approach deprived the older composer of the momentum required to anticipate Wagner's musical developments. Iphigénie en Aulide brought these tensions to the forefront, and it became a major focal point in the ongoing struggle to reevaluate Gluck, as both sides presented their arguments-both critical and musical-for his place in music history.

\section{REFERENCE LIST}

\section{Periodicals}

Le Figaro, 1907

Le Guide musical, 1906-1908

Le Ménestrel, 1906-1908

Le Mercure de France, 1906-1908

Le Monde artiste, 1907-1908

Musica, 1906-1908

La Revue musicale, 1906-1908

34 For more on the role of Landowska and the harpsichord in reviving seventeenth-century French keyboard music at this time, see Annegret Fauser, "Creating Madame Landowska," (Fauser 2006b). Thanks to Dr. Fauser for sharing her work on this with me. 


\section{BIBLIOGRAPHY}

Berlioz, Hector. 1971. A travers chants. Paris: Gründ.

Clément, Félix. 1885. Histoire de la musique, depuis les temps anciens jusquà nos jours. Paris: Hachette, 1885.

Debussy, Claude. 1987. Monsieur Croche et autres écrits, ed. François Lesure. Paris: Gallimard.

Diderot, Denis. 1967. Paradoxe sur le comédien, précédé par des Entretiens sur le Fils naturel. Paris: Garnier-Flammarion.

Ellis, Katharine. 1995. Music Criticism in Nineteenth-Century France. Cambridge: Cambridge University Press. 2005. Interpreting the Musical Past: Early Music in Nineteenth-Century France. Oxford and New York: Oxford University Press.

.2006. "En Route to Wagner: Explaining d'Indy's Early Music Pantheon."

In Vincent d'Indy et son temps, ed. Manuela Schwartz, 111-21. Sprimont, Belgium: Mardaga.

Fauquet, Joël-Marie. 2000. "Berlioz and Gluck." In The Cambridge Companion to Berlioz, ed. Peter Bloom, 199-210. Cambridge: Cambridge University Press.

Fauser, Annegret. 2005. Musical Encounters at the 1889 Paris World's Fair. Rochester: University of Rochester Press.

2006a. "Archéologue malgré lui: Vincent d'Indy et les usages de l'histoire." In Vincent d'Indy et son Temps, ed. Manuela Schwartz, 123-33. Sprimont, Belgium: Mardaga.

. 2006b. "Creating Madame Landowska." Women \& Music, Vol. 10 (forthcoming).

Fulcher, Jane F. 1999. French Cultural Politics and Music: from the Dreyfus Affair to the First World War. New York: Oxford University Press.

Grey, Thomas S. 1988. "Wagner, the Overture, and the Aesthetics of Musical Form." 19th-Century Music, Vol. 12, 3-22.

Hayes, Jeremy. 2006. "Iphigénie en Aulide." In Grove Music Online, ed. Laura Macy (accessed September 30, 2006). Available online at $<w w w . g r o v e m u s i c$. com>.

Indy, Vincent d'. 1927. La Schola Cantorum en 1925. Paris: Bloud \& Gay. . 2001. Ma Vie: Journal de jeunesse, Correspondance familiale et intime, 1851-1931, ed. Marie d'Indy. Paris: Séguier.

Médicis, Catrina Flint de. 2006. "The Schola Cantorum, Early Music, and French Nationalism from 1894 to 1914." Ph.D. diss., McGill University.

Millington, Barry. 1984. Wagner. Princeton: Princeton University Press.

Nichols, Roger. 1998. The Life of Debussy. Cambridge: Cambridge University Press.

Pasler, Jann. 1991. "Paris: Conflicting Notions of Progress." In The Late Romantic Era: From the Mid-19th Century to World War I, ed. Jim Samson, 389-416. Englewood Cliffs, New Jersey: Prentice Hall.

Rees, Brian. 1999. Camille Saint-Saëns: A Life. London: Chatto \& Windus. 
Rolland, Romain. 1908. Musiciens d'autrefois. Paris: Librairie Hachette. Translated by Mary Blaiklock as Some Musicians of Former Days. London: Paul, Trench, Trubner and Co., 1915.

Thomson, Andrew. 1996. Vincent d'Indy and his World. Oxford: Clarendon Press.

Tiersot, Julien. 1919. Gluck. $4^{\text {th }}$ Ed. Paris: Alcan.

Udine, Jean d'. 1906. Gluck. Paris: Librairie Renouard.

Vallas, Léon. 1929. The Theories of Claude Debussy, Musicien français, trans.

Maire O'Brien. London: Oxford University Press. . 1946, 1950. Vincent d'Indy, 2 vols. Paris: Albin Michel.

Wagner, Richard. 1841. "De L'Ouverture." La Revue et gazette musicale de Paris, Vol. 8, Nos. 4-6 (10, 14, and 17 January). . 1854. "Glucks Ouvertüre zu Iphigenia in Aulis." Neue Zeitschrift für Musik (1 July 1854).

1992. My Life, trans. Andrew Gray, ed. Mary Whittall. New York: Da Capo Press.

Wolff, Stéphane. 1953. Un demi-siècle d'Opéra-Comique (1900-1950). Paris: Bonne.

\section{ABSTRACT}

In December 1907, Gluck's opera Iphigénie en Aulide was produced in Paris at the OpéraComique, the last of his major operas to be revived in France. The ensuing critical reception pitted Vincent d'Indy, who harshly criticized the production, against its director, Albert Carré; d'Indy further responded by conducting the overture to Iphigénie only a few weeks later as a musical corrective to the performance at the Opéra-Comique. This unusual event highlights the historiographic problem Gluck presented to early twentieth-century critics in France: did his music look backwards to the tragédies lyriques of Lully and Rameau, or did it prefigure the Wagnerian music-dramas of the nineteenth century? The 1907 Opéra-Comique production of Iphigénie and its aftermath encapsulate the struggle to incorporate Gluck into newly developing and often competing narratives of music history.

\section{RÉSUMÉ}

Dernier des principaux opéras de Gluck à être représenté après une période doubli, Iphigénie en Aulide a été produit à l'Opéra-Comique de Paris en décembre 1907. La réception critique qui suivit opposa Vincent d'Indy, féroce critique de cette production, et son directeur, Albert Carré. D’Indy répliqua dans les semaines suivantes en dirigeant louverture d'Iphigénie à titre de rectificatif musical de la présentation de l'Opéra-Comique. Cet événement inhabituel met en évidence le problème historiographique posé par Gluck aux critiques français du début du XXe siècle : sa musique était-elle orientée vers le passé des tragédies lyriques de Lully et Rameau ou préfigurait-elle les drames musicaux wagnériens du XIXe siècle? La production d'Iphigénie à l'Opéra-Comique en 1907 et ses séquelles résume le combat visant à intégrer Gluck dans de nouvelles, et souvent concurrentes, trames de l'histoire de la musique. 